\title{
A rare case of an evolutionary late and ephemeral biomineralization: tunicates with composite calcareous skeletons
}

\author{
Jobst Wendt (1) \\ Fachbereich Geowissenschaften der Universität Tübingen, Germany <jobst.wendt@uni-tuebingen.de>
}

\begin{abstract}
In contrast to almost all other invertebrate phyla that constructed biomineralized skeletons during the "Cambrian explosion" and maintained them during the entire fossil record, ascidian tunicates evolved this protective and stabilizing advantage only during the Permian, although soft-bodied representatives of this subphylum made their first appearance already in the early Cambrian. It remains enigmatic why these compound calcareous skeletons persisted only until the Late Triassic, subsequently followed by less-rigid internal skeletons from the Lower Jurassic onwards, which consist of scattered isolated spicules only. In addition to recently described aragonitic ascidian exoskeletons from the Permian and Triassic, new discoveries of similar, but colonial ascidian compound endoskeletons in the lower Carnian exhibit a short-living branch of this group, which moreover contain the first indubitable calcareous spicules. The latter are embedded in the solid endoskeleton, which is composed of polygonal aragonitic plates with smooth outer and zigzag lined inner boundaries. They consist of irregular, parallel (orthogonal), or fan-shaped (clinogonal) arrangements of acicular aragonite crystals. The following taxa are described as new: order Cassianomorpha new order with the family Cassianosomidae new family and the genus Toscanisoma new genus with the species T. multipartitum new species and T. triplicatum new species.
\end{abstract}

UUID: http://zoobank.org/03555353-cdab-42e8-8e99-9bfce15fa249

\section{Introduction}

Biologically controlled biomineralization is a fundamental process in the evolution of the animal kingdom. Though it was sporadically achieved already in the latest Precambrian, the so-called "Cambrian explosion," ca. 540 Ma ago, marks the general advent of animals with hard parts in the fossil record. It is well known, that this event was not an instantaneous process, but that it was accomplished in a time span of ca. 20-25 Ma (Lowenstam and Margulis, 1980; Chen et al., 1997; Thomas et al., 2000; Kouchinsky et al., 2012; Zhuravlev and Wood, 2018). The acquisition and evolution of hard skeletons within the great majority of phyla and classes are the basic prerequisites for the reconstruction of animal form and function through time. Once hard parts were created in order to protect and stabilize soft tissues and organs, this evolutionary advantage indeed developed a great variety of morphologies, but in spite of this diversity and modification, solid skeletons were generally maintained as such until extinction of the equivalent groups.

A similar reduction of a hard skeleton into a mere softbodied stage seems achieved in some Coleoidea and Opisthobranchia (see below), but this accordance is based on notional paleontological evidence. An alleged late acquisition of a hard skeleton inherited from soft-bodied ancestors is suspected in Bryozoa and Scleractinia (see below), but in contrast to ascidians, once these groups had acquired calcified skeletons, they maintained this protective and stabilizing advantage until Recent. Thus, the very late acquirement of a solid calcareous skeleton among Tunicata and its later loss in favor of an almost soft-bodied stage is a very rare phenomenon in the geological record. This article describes and decrypts such an unusual case in the fossil rather poorly known class Ascidiacea of the subphylum Tunicata.

From their form and mode of life, Ascidiacea (sea squirts) appear as rather simple-structured organisms that superficially and functionally are evocative of Porifera. But the presence of a tubular dorsal nerve cord and a notochord in their larval stage and pharyngeal clefts allocates them a much higher position within the animal kingdom as a subphylum of the Chordata. Ascidians are an artificial, polyphyletic group that comprises three orders (Aplousobranchiata, Stolidobranchiata, Phlebobranchiata) with a total of 2940 living species (Burda et al., 2016). They generally lack hard parts, thus minimizing the possibility of preservation. Only a few genera of the orders Aplousobranchiata and Stolidobranchiata segregate tiny isolated spicules, embedded in the mantle (tunica) or other organs (Bronn, 1893-1911; Van Name, 1945; Monniot and Buge, 1971; Lambert et al., 1990), but their origin remains unknown (Lowenstam and Weiner, 1989; Varol and Houghton, 1996). Tunica is the Latin word for mantle. Therefore, many zoologists regard both terms as synonymous (e.g., Lowenstam and Weiner, 1989; Burda et al., 2016). Others, however, distinguish an inner layer (tunic), in which the spicules are secreted, from an outer one (mantle; Brusca et al., 2016). In order to guard against misunderstandings, in the present article both terms are used as synonyms because, with regard to fossils, the differential application of both terms would appear arbitrary.

Spicules of congeneric predecessors among the above mentioned orders have been found in rocks as old as lower Liassic 


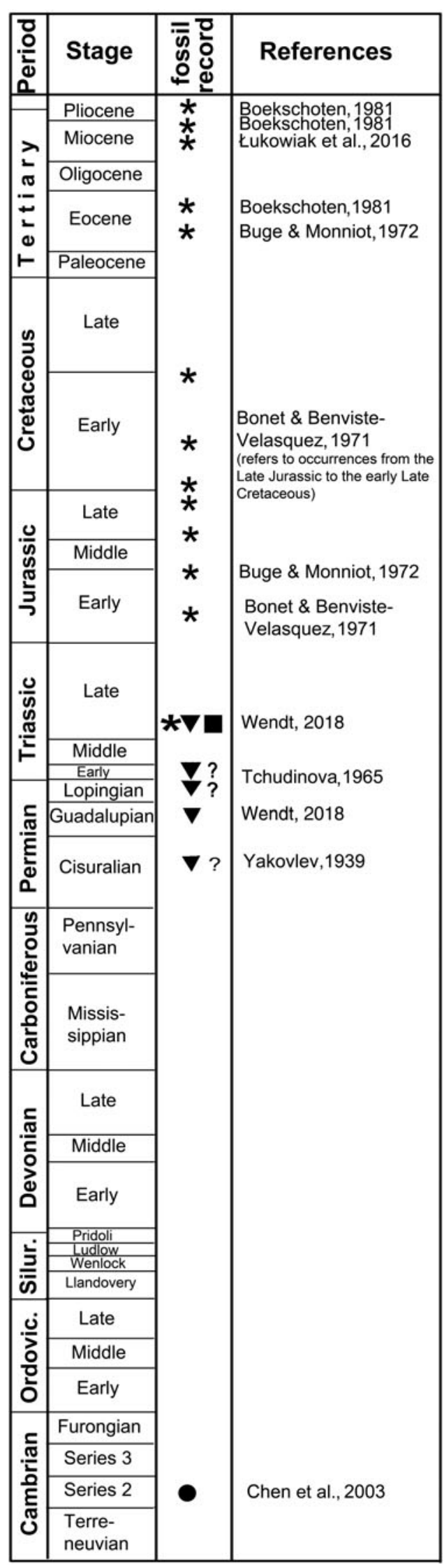

Figure 1. Fossil record of tunicates. Black dot $=$ soft-bodied; black triangles $=$ calcareous exoskeletons; black square $=$ calcareous endoskeletons; asterisks $=$ spicules (modified from Wendt, 2018).
(Fig. 1; Bonet and Benviste-Velasquez, 1971; Varol and Girgis, 1994). Generally, ascidian spicules consist of aragonite, more rarely of vaterite or other minerals (Lowenstam and Weiner, 1989). Unlike some siliceous sponge spicules, they are never fused together and thus could not form solid skeletons. The discovery of complete soft-bodied ascidians (lacking spicules, however) in the lower Cambrian of China (Chen et al., 2003) has revealed that ascidians existed already at an early stage of metazoan evolution, but this finding does not allow to reconstruct their relationships to Mesozoic to recent representatives of this class. A new evolutionary branch among ascidians is the recent discovery of calcareous tunicate exoskeletons in the Upper Triassic and their ancestors in the Permian (Wendt, 2018). In this article it has been demonstrated that these very unusual skeletons, which are composed of irregular aragonitic plates, can be assigned to no phylum other than to tunicates. This systematic position of these previously unknown organisms to the class Ascidiacea has been the fundamental clue for the systematic attribution of the new discoveries described in the present article. The fact, however, that they are endoskeletons (see below), opens an unusual insight into a new aspect of the evolution of this poorly known class which has no counterpart among their living representatives. Tunicate exoskeletons have long been known from Permian deposits in east Asia and Europe, but until recently they were erroneously attributed to rugose corals (Montanaro-Gallitelli, 1956; Wendt, 2018). These skeletons are composed of a varying number ( 2 to 35 ) of irregular plates that consist of acicular aragonite. This very unusual construction and mineralogy were crucial for their systematic attribution, though similar living representatives of this class are unknown. Comparably organized endoskeletons now add a new aspect to the fossil record of this largely ignored subphylum of the Chordata. The subsequent paragraphs are mainly devoted to these newly discovered endoskeletons.

Endoskeletons are widespread in the animal kingdom and display a great variety of shape, function, and mineralogical composition. They are typical for the major phyla of Deuterostomia (Echinodermata and Vertebrata, including Conodontophorida) and many Protista (Foraminifera and Radiolaria), which exhibit a stunning variety of shapes and geometries. Endoskeletal spicules (sclerites) of different mineralogical composition evolved independently among several phyla and classes (Porifera, Octocorallia, Vermes, Holothuroidea, Tunicata). Apart from the calcareous octocoral Tubipora musica (see Spiro, 1971), only some Porifera (Hexactinellida and Lithistida), produced siliceous spicules, which are fused or articulated into compound endoskeletons forming cubic or irregular meshworks, thus giving more stability to the soft body. Among other phyla, compact solid calcareous endoskeletons occur only among the Mollusca (Coleoidea; for a different interpretation see Thomas and Reif, 1991). Composite calcareous endoskeletons consisting of numerous plates with flexible boundaries are characteristic for Echinodermata and for the newly discovered fossil Tunicata.

\section{Provenance}

Only two incomplete specimens were available for the present study. They are derived from the same formation and locality 
as the tunicate exoskeletons mentioned above (Fig. 1). Extensive search for additional, either biostratigraphically older, contemporaneous, or younger specimens from European and North American reef specialists and collections remained unsuccessful. The two specimens were discovered among far over a million of skeletal remains in the Cassian Formation (lower Carnian) of the Dolomites (northern Italy; references in Wendt, 2018). The number of taxa and the diversity of skeletal remains collected from the Cassian Formation during almost two centuries are indeed impressive and assign this rock unit a singular rank among the "Fossil-Lagerstätten" in the geological record. According to Roden et al. (2019), 1429 species have been described so far from this formation. A special feature of this unrivaled fauna is their often excellent state of preservation, exemplified by diagenetically almost unaltered aragonitic microstructures, which are among the oldest in earth history. In this state of perfection and considering its age, the Cassian fauna can even be regarded as unique.

\section{Morphology and growth}

Both specimens are incomplete colonies that were probably attached to a firm- or hardground on the sea-floor. Similar growth forms also are common among living ascidians (e.g., Amarovicium, Synocium [Bronn, 1893-1911], and Polycarpa [Monniot, 2002]). In Toscanisoma multipartitum the base of the colony is not preserved (Fig. 2.4), but Toscanisoma triplicatum (for diagnosis see below, paragraph Systematic Paleontology) shows an undamaged flattened base (Fig. 3.3, 3.4). The most remarkable feature is the fact that the outer surface of both species is completely smooth and that growth lines are totally lacking. Also, by staining of thin sections with Mutvei solution (Schöne et al., 2005), which often reveals concealed growth increments, no traces of marginal accretion within the plates could be detected. The irregular wrinkles in the basal portion of Toscanisoma triplicatum n. gen. n. sp. (Fig. 3.3, 3.4) display an irregular upgrowth, which must not be mistaken for growth lines. The skeleton is composed of polygonal or rounded plates of very contrasting size and outline. The smallest plates ( $2 \times 2 \mathrm{~mm}$ across) are observed at the top of the only complete zooid of Toscanisoma multipartitum (Fig. 2.1, 2.3), the largest ones $(7 \times 10 \mathrm{~mm})$ in the more basal portions of both species described below. The plates fit closely together and show very faint boundaries on the outer side (Figs. 2.1, 2.2, 3.1). At a first glance they appear as post-mortem cracks, but the corresponding inner surfaces show that the plates are separated by distinct zigzag sutures similar to Zardinisoma (Ascidiacea, order Khmeriamorpha, Wendt, 2018) (Figs. 2.1, 2.2, 3.2). Careful preparing of the interior of individual zooids did not reveal any skeletal structures such as tabulae, septa or dissepiments. Budding in Toscanisoma multipartitum starts at the base, but in T. triplicatum only $20 \mathrm{~mm}$ higher up, just showing the incipient division of the basal cup into three zooids, the distal parts of which are not preserved (Fig. 3.5).

\section{Mineralogy and microstructure}

Staining of thin sections with Feigl-solution and x-ray diffraction analysis reveal that the skeletons consist of aragonite. The presence of minor amounts of calcite must be attributed to traces of early cements and/or post-depositional diagenetic alterations. The latter have also affected the majority of the original aragonite crystals, which are generally micritized (Fig. 5.3, 5.4) or transformed into larger ones (Fig. 5.6) whose mineralogical composition (aragonite or calcite) cannot be determined with the SEM. Several portions of the skeleton, however, retain the
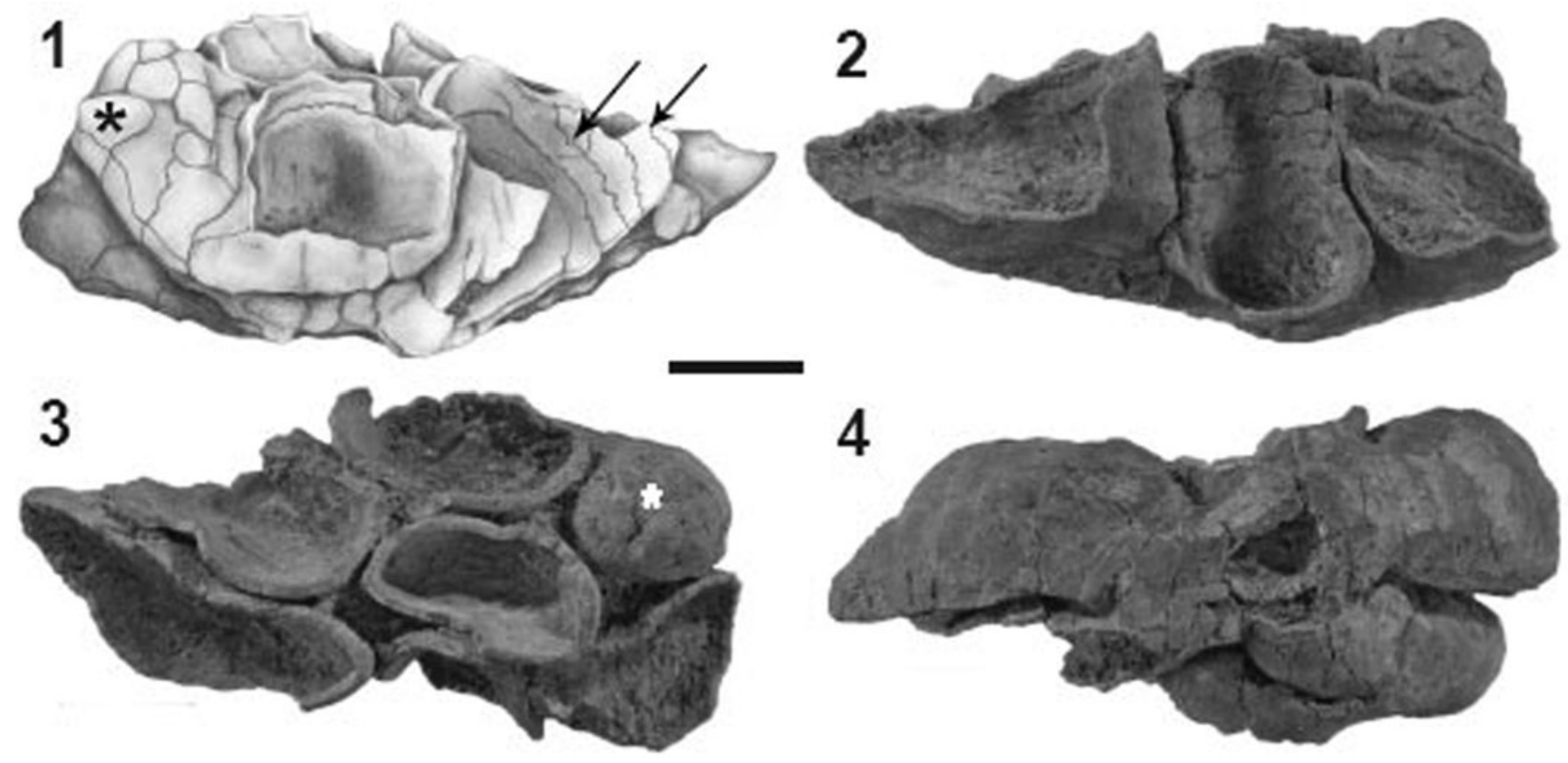

Figure 2. Toscanisoma multipartitum holotype (GPIT/TU 82). (1) Lateral view (drawing); (2) opposite side; (3) view from top; (4) base. Asterisks mark complete zooids, arrows indicate zigzag sutures on inner surfaces. Scale bar $=10 \mathrm{~mm}$. 

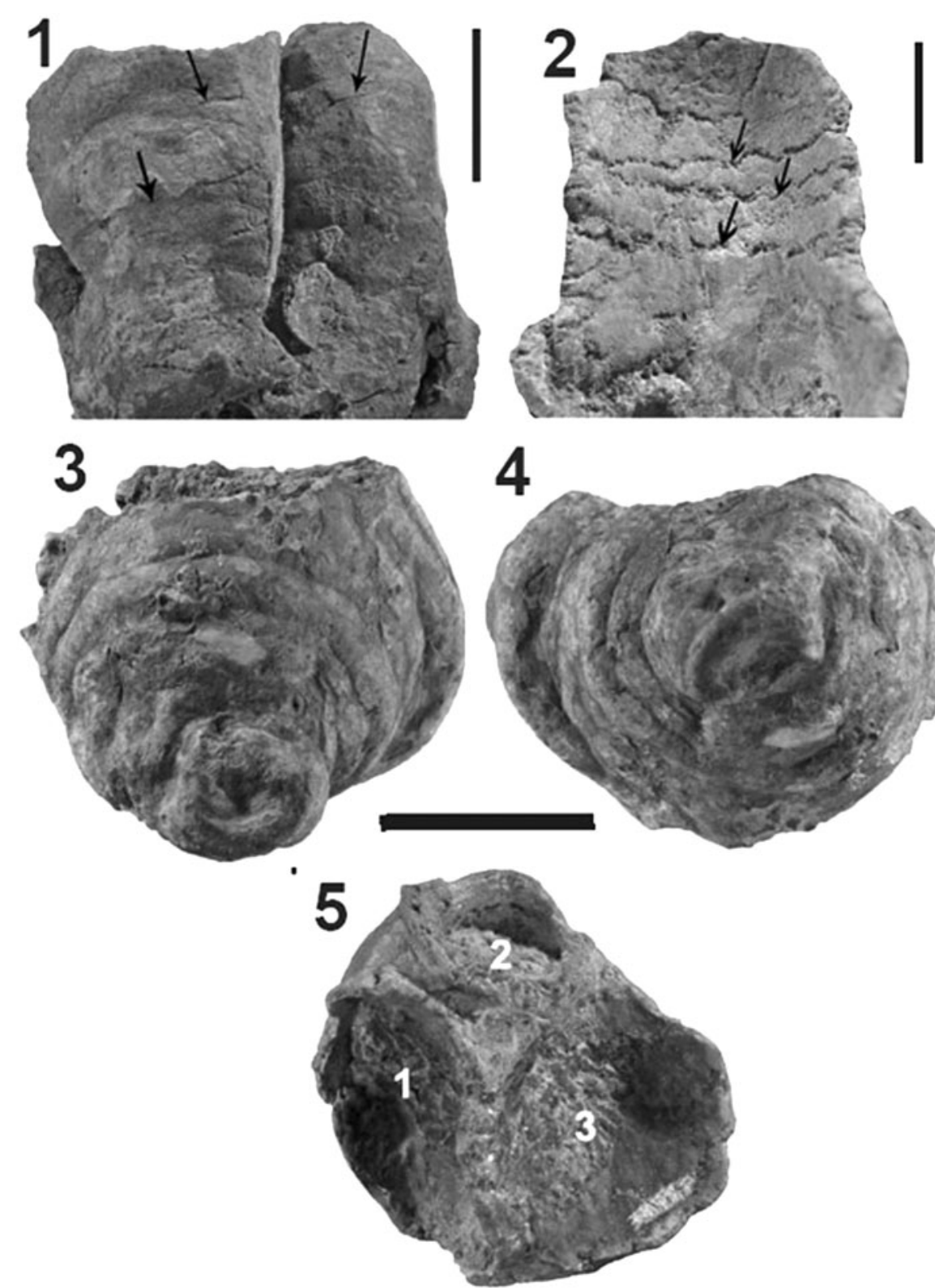

Figure 3. (1,2) Toscanisoma multipartitum holotype (GPIT/TU 82). (1) Lateral view of 2 zooids, arrows indicate outer plate boundaries; (2) close-up of Figure 2.2; note zigzag boundaries of half ring-like plates (arrows). (3-5) Toscanisoma triplicatum holotype (GPIT/TU 83). (3) Lateral view; (4) view from base; (5) view from top; 1, 2, 3 mark cavities of three incomplete zooids. Scale bars for $(\mathbf{1}, \mathbf{2})=5 \mathrm{~mm} ;(\mathbf{3}-\mathbf{5})=15 \mathrm{~mm}$.

original microstructure, which consists of up to $30 \mu \mathrm{m}$ long and 2-4 $\mu \mathrm{m}$ wide acicular crystals. Their three-dimensional arrangement is similar to that of coralline sponges (Wendt, 1984). Sun et al. (2017) have shown that acicular aragonite crystals in scleractinian corals grow 10 times faster along the $\mathrm{c}$-axis than along the a-axis. From their similar dimensions, this differential growth rate can also be assumed for the crystals of the fossil ascidians. They are mostly arranged irregularly (Fig. 5.1, 5.2, 5.5), but locally also fan-shaped (clinogonally) (Fig. 5.3, 5.4). Towards the inner and outer sides of the plates, the crystals are generally arranged parallel (orthogonal) and perpendicular to the surfaces (Fig. 4.4). The patchy arrangement of the isolated or bundled crystals shows that biomineralization started more or less simultaneously at several nucleation points within the entire mantle (tunica), but it cannot be decided if this has been an endo- or extracellular process. Growth of the crystals was inhibited by contact with adjacent ones, thus resulting in a dense irregular porous meshwork that was probably infused with soft tissue. This growth pattern is totally different from the endoskeletons of echinoids and belemnites (which both show evident growth lines), but it resembles that of spherical spicules of some living ascidians (Monniot, 1970).

A very surprising discovery in SEM observations is the presence of rare calcareous monaxon spicules, up to $140 \mu \mathrm{m}$ long and 2-10 $\mu \mathrm{m}$ thick, embedded in the crystalline skeleton of Toscanisoma triplicatum. They are the oldest unquestionable spicules of ascidians ever reported. One spicule has a rounded 

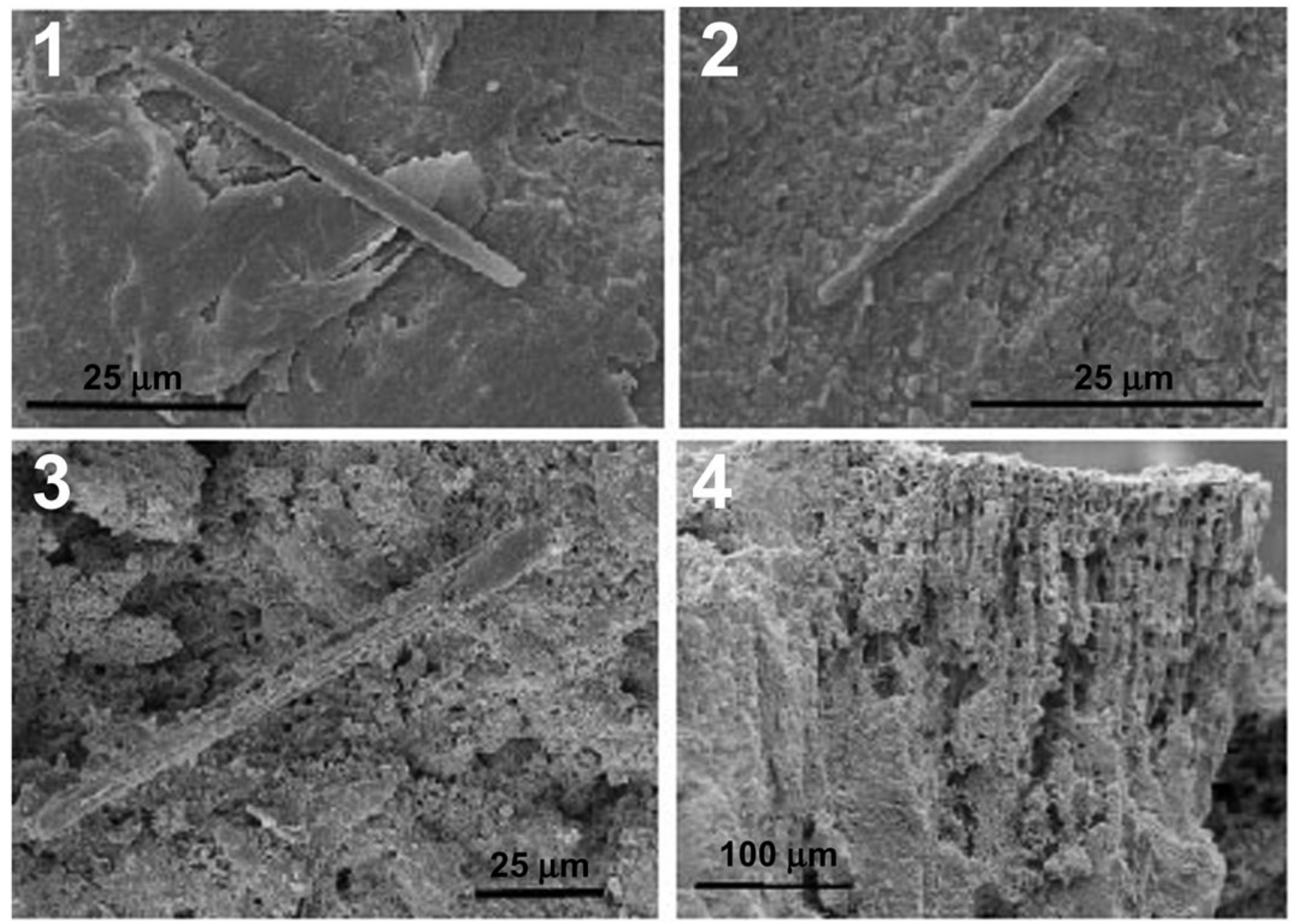

Figure 4. Toscanisoma triplicatum holotype (GPIT/TU 83). (1-3) Spicules; (4) orthogonal microstructure.

globular end and an acute top resembling monaxon spicules (tylostyles) of siliceous sponges (Fig. 4.1). The smooth surface and the obliquely fractured end suggest that this spicule may be a single crystal, a feature that is not known from other fossil or living tunicates. Another monaxon spicule is slightly arcuate and has tapering ends (Fig. 4.2). These simple spicules are obviously the most primitive ones, but are also known from fossil and living genera such as Herdmania and Pyura, which belong to the order Stolidobanchiata (Van Name, 1945; Monniot, 2002). The third type of spicule, which is the longest one $(140 \mu \mathrm{m})$, has regular longitudinal ridges and grooves (Fig. 4.3). This type has never been observed in fossil or recent ascidians, but resembles the individual rays of spherical spicules (Varol and Houghton, 1996). The scarcity of these spicules shows that they had no essential importance for the stability of the skeleton, but they document the presence of specialized cells (scleroblasts) within the mantle (tunica) and/or the adjacent inner epithelium. The intimate intergrowth of the spicules with the crystals of the skeleton and the total absence of growth increments in the latter clearly indicate that the entire skeleton was formed within the tunica or mantle and that it is consequently an endoskeleton. In living ascidians spicules may migrate into blood vessels and internal organs (Lowenstam and Weiner,
1989), but it is impossible to imagine that they moved into a solid skeleton.

\section{Comparisons}

Only few examples within the fossil record have been reported in which an endo- or exoskeleton has successfully been constructed not only very late in the evolution of a higher ranking taxon, but was later again abandoned in favor of a return to an almost softbodied stage. In gastropods, a secondary shell loss seems to have occurred several times, in particular in the subclasses Pulmonata and Opisthobranchia, in which relics of larval shells may be still present but were subsequently resorbed (Brusca et al., 2016). This feature is found in the suborder Nudibranchia, but due to its lacking fossil record, their phylogeny and position within the subclass Opisthobranchia is unknown (Wollscheid-Lengelin et al., 2001; Hallas et al., 2016) and their evolution from hard- to soft-bodied organisms remains speculative. Another comparable example is typified by some living soft-bodied Octopoda of the subclass Coleoidea (Cephalopoda) whose skeleton (gladius)bearing living representatives (e.g., Vampyroteuthis) may have evolved by decalcification from Cretaceous phragmoconebearing ancestors (Fuchs and Iba, 2015; Sutton et al., 2016). 

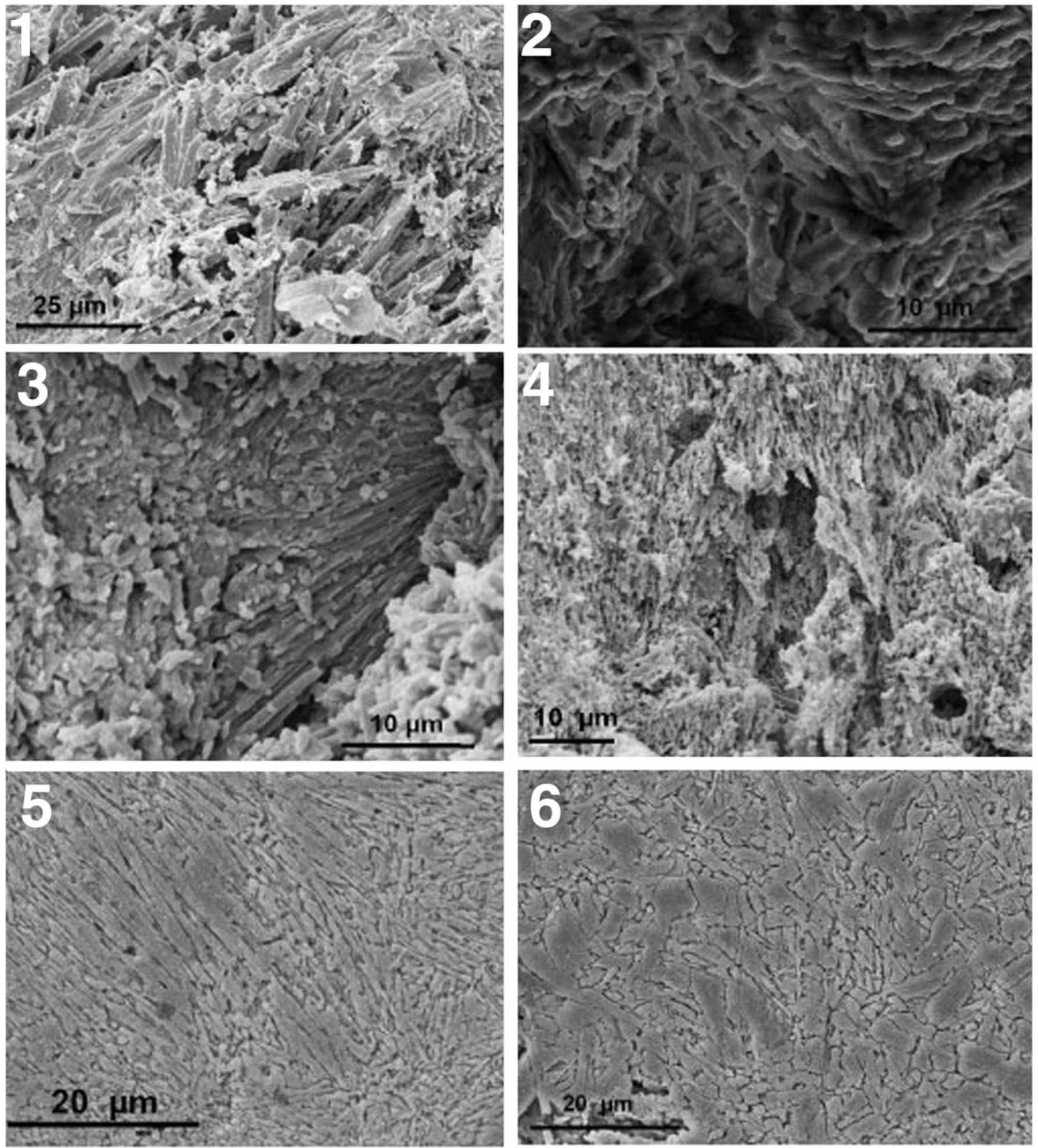

Figure 5. Microstructures. $(\mathbf{1}, \mathbf{4 , 5})$ Toscanisoma multipartitum. $(\mathbf{2 , 3 , 6 )}$ Toscanisoma triplicatum. $(\mathbf{1 , 2 , 5 , 6 )}$ Irregular microstructure; $(\mathbf{3 , 4})$ clinogonal microstructure (partly micritized). (1-4) Artificially broken cross sections; $(\mathbf{5}, \mathbf{6})$ polished and EDTA-etched surface-parallel thin sections showing original irregular $(\mathbf{5})$ and recrystallized (6) microstructure.

Unfortunately, intermediate forms from the Tertiary, which would corroborate this assumption, are still lacking (personal communication, D. Fuchs, 2019). One may also regard the relatively late appearance of hard skeletons of Bryozoa in the
Ordovician as a faintly comparable example, but their presumed origin from soft-bodied late Cambrian progenitors (Pywackia [see Landing et al., 2015]) is very contentious. Also the late arrival of scleractinian corals in the early Middle Triassic 
might represent a comparable evolutionary step from soft-bodied to skeleton-bearing organisms, if one accepts that their possible ancestors must be searched among Paleozoic soft-bodied sea anemones (Stanley, 2003; Stolarski et al., 2011; Janiszewska et al., 2015). In fact, this hypothesis is widely accepted among specialists of scleractinian evolution. But their direct relationship with rugosan corals is still a matter of debate, although the missing links in the early Triassic remain to be discovered (Cuif, 1977; Stolarski, 1996). In this respect, it is worth noting that a late Paleozoic rugose coral (Numidiaphyllum) from the upper Permian of Tunisia not only possessed an originally aragonitic (recrystallized) skeleton, but also displayed a scleractinian pattern of cyclic septal insertion (Wendt, 1990). This unusual case might support the assumption that Rugosa were possible ancestors of Scleractinia. Scleractinian-like Rugosa were also reported from the Ordovician, suggesting that this "Bauplan" was already established in the early Paleozoic (Ezaki, 1998). But in contrast to these still rather speculative similarities and assumed evolutionary trends, the discovery of tunicate spicules in the Late Triassic reveals a direct relationship to their soft-bodied descendants in the Early Jurassic. These arguments indeed allocate endo- and exoskeleton-bearing Ascidiacea a singular position in the fossil record.

\section{Material and methods}

Methods of study included manual preparation, thin sectioning, staining with Feigl-solution, SEM, and x-ray diffraction. SEM observations were performed on fresh fracture surfaces (thus avoiding contamination), on untreated outer and inner plate surfaces and on polished thin sections, which were etched with Mutvei-solution or EDTA (Marin et al., 2007).

Repository and institutional abbreviation.-Types, figures, and other specimens examined in this study are deposited in the collections of the Geological-Paleontological Institute of the University of Tübingen under the numbers GPIT/TU 1-83.

\section{Systematic paleontology}

\section{Subphylum Tunicata Lamarck, 1816 Class Ascidiacea Blainville, 1824 Order Cassianomorpha new order}

Diagnosis.-Colonial sessile Ascidiacea composed of 3-7 (eventually more) diverging hollow tubes (zooids) forming a compound solid aragonitic skeleton. The latter has a smooth outer surface without any traces of external and/or internal growth lines and is therefore interpreted as an endoskeleton that was secreted within the soft-bodied mantle (tunica). Individual zooids are composed of $>10$ irregular plates each, which have smooth, barely visible, straight or slightly curved margins on the outer and zigzag ones on the inner surface, suggesting a certain flexibility. The microstructure consists of acicular crystals of aragonite, up to $30 \mu \mathrm{m}$ long and 2-4 $\mu \mathrm{m}$ wide. Internal skeletal elements, such as septa, tabulae, or dissepiments, have not been observed. For dimensions, see Table 1.
Table 1. Measurements of species of Toscanisoma.

\begin{tabular}{lll}
\hline & T. multipartitum & T. triplicatum \\
\hline Number of zooids & 7 & 3 (or more) \\
Width of colony (mm) & $55 \times 30$ & $30 \times 25$ \\
Height of colony (mm) & 28 & 26 \\
Max. diameter of individual & $17-29$ & $11-19$ \\
$\quad$ zooids (mm) & & \\
No. of plates per zooid & $\sim 10-16$ & 10 \\
Size of plates (mm) & $2 \times 2$ to $6 \times 10$ & $3 \times 13$ to $7 \times 8$ \\
Wall thickness (mm) & $1.3-1.8$ & $1.1-1.6$ \\
Apical angle & $135^{\circ}$ & $80^{\circ}$ \\
\hline
\end{tabular}

Etymology.-After the Cassian Formation (Upper Triassic, northern Italy $)$, morph $($ Greek $)=$ shape

Remarks.-The apical plates could presumably be unfolded in order to outstretch the atrial and branchial siphons. Movement of the plates was probably achieved by muscles, which were fixed in the porous marginal portions of the plates. The lack of growth lines, the local presence of spicules in one species, and the colonial growth form clearly distinguish the new order from Khmeriamorpha (Wendt, 2018).

Family Cassianosomidae new family

Diagnosis.—As for order.

Etymology.-After the Cassian Formation. Soma $($ Greek $)=$ body.

\section{Genus Toscanisoma new genus}

Type species.—Toscanisoma multipartitum $\mathrm{n}$. sp.

Diagnosis.-A colonial form consisting of up to seven (possibly more) cylindrical tubes (zooids) which bud from the base and diverge at an angle of $80-135^{\circ}$. The zooids fit closely together at their bases, but leave narrow open interspaces higher up. Each zooid is composed of a varying number of irregular plates, which show faint straight or curved boundaries on the outer surface and zigzag sutures on the inner one. Rare spicules embedded in the calcareous endoskeleton were observed in one species (T. triplicatum).

Occurrence.-Cassian Formation (lower Carnian), Dolomites (Italy).

Etymology.-After Maria Luigia Toscani (Cortina d'Ampezzo, Italy), collector of fossils from the Cassian Formation, who donated the specimens for the present study. Soma $($ Greek $)=$ body .

Remarks.-The colonial growth form consisting of several (seven, possibly more) zooids budding from a common center shows relationships to morphologically similar living genera of Ascidiacea that, however, are soft-bodied (see above). This growth form is also typical for phaceloid rugosan and scleractinian corals, but in contrast, the new genus does not display any internal skeletal elements. Compound, solid 
calcareous skeletons are unknown from living genera of Ascidiacea.

\section{Toscanisoma multipartitum new species}

Figures 2, 3.1, 3.2, 5.1, 5.4, 5.5

Holotype.-Figures as above; GPIT/TU 82.

Diagnosis.-A sessile colonial species consisting of seven branching tubes (zooids) composed of irregular plates that are joined by straight or curved boundaries on the outer and zigzag ones on the inner side. The only complete zooid of the colony is closed at the top by six plates that are smaller than the remaining ones. The other zooids are incomplete, but were probably slightly larger. Spicules have not been observed. For measurements see Table 1 .

Occurrence.-Alpe di Specie (Seelandalpe) near Cortina d'Ampezzo (Dolomites, northern Italy), Cassian Formation (lower Carnian).

Description.-The only specimen available for the present study is not complete, lacking the basal portion, which probably served as a holdfast. The seven zooids, which bud from the flattened base, have different shapes ranging from almost circular to elongate or flattened in cross section. Only the smallest zooid is complete, $25 \mathrm{~mm}$ long and consists of $\sim 10$ plates with very faint and barely recognizable outer boundaries (exaggerated in the drawing of Fig. 2.1). The inner plate boundaries of the incomplete zooids show zigzag sutures similar to contemporaneous representatives of the order Khmeriamorpha (Wendt, 2018). The zooids fit closely together at the base and are separated by small open interspaces higher up.

Etymology.-Multipartitum $\quad($ Latin $)=$ consisting of several parts.

Remarks.-By careful manual preparing and etching with diluted (10\%) acetic acid, some inner plate boundaries could be uncovered exhibiting typical zigzag boundaries (Figs. 2.1, 3.2). It must be assumed that the incomplete zooids of the colony were also closed by small plates similar to the only complete one (Fig. 2.1, 2.3). The entire colony might have reached a height of up to 5-6 cm and a width of $\sim 7-8 \mathrm{~cm}$, but their exact final size cannot be calculated. Spicules embedded in the solid skeleton have not been observed.

\section{Toscanisoma triplicatum new species}

Figures 3.3-3.5, 4, 5.2, 5.3, 5.6

Holotype.-Figures as above; GPIT/TU 83.

Diagnosis.-A sessile colonial species consisting of three (eventually more) zooids, which bud at a certain distance from the basal cup. The apical angle of the colony is $\sim 80^{\circ}$. Rare monaxon spicules of different size and shape are embedded in the porous skeleton. The distal portion of the zooids is not preserved. The outer surface of the basal part shows irregular swellings and faintly recognizable straight boundaries of individual plates with polygonal outlines. For measurements see Table 1.

Differential diagnosis.-The species is distinguished from T. multipartitum by the presence of spicules, the different kind of budding, in which the separation into three individual zooids starts at a distance of $\sim 2 \mathrm{~cm}$ above the base. Thus, in their early growth stage, the individual zooids share the outer walls of the adjacent ones, but higher up than in T. multipartitum.

Occurrence.-Alpe di Specie (Seelandalpe) near Cortina d'Ampezzo (Dolomites, northern Italy), Cassian Formation (lower Carnian).

Etymology. -Triplicatum $=$ triplicate $\quad$ (consisting of three zooids).

Remarks.-Because of the fragileness of the specimen, the inner side of the basal cup and the individual zooids could not be sufficiently prepared, but it is assumed that the inner plate boundaries show zigzag sutures similar to T. multipartitum. Due to the incomplete state of preservation and the lack of comparable material, speculations about the final growth form and the number of zooids are premature.

Zardini (1981, pl. 23, fig. 10) figured a specimen determined as "?Spondylus zardinii (Leonardi)" from the Cassian Formation near Cortina d'Ampezzo, which bears a certain resemblance to the new species. It consists of four (or six?) closely fitting tubes of similar size as those in T. triplicatum, which are open at their distal parts and thus are probably incomplete. Unfortunately, the original specimen could not be traced in the non-cataloged and rather disordered collections of the author deposited in the Museo Zardini at Cortina d'Ampezzo. I suppose that additional specimens that might show a much more reliable relationship to the here established new species (and to T. multipartitum) could be rediscovered in the immense collections of the late Rinaldo Zardini, which contains far over a million specimens and is worldwide unique.

\section{Discussion}

The above sketched morphological and mineralogical features raise the pivotal question of the systematic attribution and the functional morphology of these enigmatic remains. Solid skeletons (whether exo- or endo-) composed of irregular plates that consist of acicular aragonite crystals are unknown in the animal kingdom - with one exception: Permian/Triassic ascidian tunicates with a compound calcareous skeleton, which appeared in the early(?) Permian and became extinct during the Late Triassic (Wendt, 2018). The reason for this surprising taxonomic attribution has been discussed at length in a previous article (Wendt, 2018). These remains reveal a certain relationship to some living ascidians (e.g., Chelyosoma and Forbesella, later attributed to Pyura; Bronn, 1893-1911; Bancroft, 1898), although these lack any hard parts. But they are partially composed of irregular 
soft plates that can be moved by muscles (Van Name, 1945). The hinge-like sutures on the inner plate surfaces of the newly described fossil endoskeletons also suggest a certain flexibility of the compound skeleton, which is indispensable for their here proposed assignment to ascidian tunicates. The latter are filter-feeders in which a steady flow of seawater moves through an atrial and a branchial siphon. If we assign a similar function to the fossil counterparts described here, it must be required that one or two of the top plates could be opened by muscles during the life-time of the organism because this is the case in the two above-mentioned recent genera. Unfortunately, the upper part of the examined specimens generally is not preserved. But one zooid of Toscanisoma multipartitum is complete and exhibits a mosaic of tiny plates (Fig. 2.1, 2.3), which probably could be opened by muscles to allow access for the protruding siphons.

At a first glance, the presence of a solid calcareous endoskeleton in Cassianomorpha might be surprising. However, one should bear in mind that, apart from Arthropoda (which have a totally different kind of growth), all invertebrate classes with a calcareous exoskeleton show well-developed growth lines reflecting an intermittent growth at the edge of the skeleton-secreting tissue. This is not the case in the Cassianomorpha in which the skeleton is formed within the mantle (tunica) starting more or less simultaneously at several nucleation points. Faced with these observations, it is less surprising that the extinct Cassianomorpha developed an endoskeleton, as did the other main deuterostome phyla or classes (Echinodermata, Vertebrata, Jurassic to recent Ascidiacea), than the fact that the other contemporaneous fossil ascidian order Khmeriamorpha strangely developed an exoskeleton (Wendt, 2018).

\section{Conclusions}

By mid-Cambrian times, representatives of almost all metazoan phyla and subphyla had reached a high degree of biomineralization in such a way to enable a reliable reconstruction of their evolution. Why is this not the case with tunicates, which must have existed contemporaneously? One could speculate about a change in seawater chemistry or a possible global perturbation of the carbon cycle near the Carboniferous/Permian boundary (Sandberg, 1983; Stanley, 2006), but such speculations about the appearance of mineralized (aragonitic) tunicate skeletons at this interval appear rather theoretical, because the time-span of an "aragonitic ocean" (Mississippian to Middle Jurassic; Stanley, 2006) is not consistent with the existence of aragonitic ascician skeletons.

A possible answer to this fundamental question is that compound pre-Permian tunicate skeletons might have existed in earlier Paleozoic times, but they have not yet been discovered or recognized as such. It can also not be totally dismissed that they are hidden among the great number of previously described fossil Problematica or those of incertae sedis. The discovery of rare spicules embedded in the solid skeleton clearly points to a new and successful attempt of tunicate biomineralization in the Late Triassic, which persisted until recent. However, postTriassic survivors of tunicates with compound calcareous, either endo- or exoskeletons, are unknown from the fossil record. One may speculate that post-Triassic ascidians developed other protective strategies that served as a defensive function (e.g., secretion of indigestible chemicals), which, of course, cannot be detected in fossil remains. Not taking into account these theoretical considerations, the total loss of a compound calcareous skeleton in ascidians during the Late Triassic in favor of a much less stable one consisting of isolated spicules only remains an unresolved question.

\section{Acknowledgments}

I am indebted to the following persons for their support of the present study: the late R. Zardini and M.L. Toscani (both Cortina d'Ampezzo, Italy) collected and donated the majority of the studied material. W. Gerber (Tübingen) produced the photographs, N.M. Lesic (Tübingen) made the drawing of Figure 2.1., H. Schulz (Tübingen) photographed several samples under the SEM, Ch. Berthold (Tübingen) performed the X-ray diffraction analysis, P. Jeisecke (Tübingen) made the thin sections. The manuscript benefitted from the corrections and critical comments of R.D.K. Thomas (Lancaster, PA), A. Pisera (Warszawa, Poland), and an anonymous reviewer.

\section{References}

Bancroft, F.W., 1898, The anatomy of Chelyosoma Productum Stimpson: Proceedings of the California Academy of Sciences, Third Series, Zoology, v. 1 , p. 309-322.

Blainville, H.M.D. de, 1824, Mollusques, Mollusca, in Cuvier, F., ed., Dictionnaire des Sciences Naturelles: Strasbourg and Paris, Levrault and Le Normant, v. 32, p. 1-392.

Boekschoten, G.J., 1981, On ascidian actuopaleontology: Neues Jahrbuch für Geologie und Paläontologie, Monatshefte, 1981, p. 76-83.

Bonet, F., and Benviste-Velasquez, N., 1971, Espiculas de ascidias fosiles y actuals: Revista del Instituto Mexicano del Petroleo, v. 3, p. 8-35.

Bronn, H.G., 1893-1911, Tunicata (Manteltiere). I. Abteilung. Die Appendicularien und Ascidien. Begonnen von Prof. Dr. Osw. Seeliger. Fortgesetzt von Dr. R. Hartmeyer: Dr. H. G. Bronn's Klassen und Ordnungen des TierReichs, wissenschaftlich dargestellt in Wort und Bild, v. 3, Supplement, Leipzig, C.F. Winter'sche Verlagshandlung, 1773 p.

Brusca, R.C., Moore, W., and Shuster, S.M., 2016, Invertebrates. Third edition: Sunderland, Massachussetts, Sinauer Associates Inc. Publishers, $1104 \mathrm{p}$.

Buge, E. and Monniot, F., 1972, Nouveaux spicules d'Ascidies de 1'Ypresien du Bassin de Paris et du Toarcien des Deux-Sevres: Geobios, v. 5 , p. $83-90$.

Burda, H., Hilken, G., and Zrzavý, J., 2016, Systematische Zoologie. 2. Vollständig überarbeitete und erweiterte Auflage: Stuttgart, Verlag Eugen Ulmer, $398 \mathrm{p}$.

Chen, J.Y., Cheng, Y.N., and Iten, H.V., eds., 1997, The Cambrian explosion and the fossil record: Bulletin of the National Museum of Natural Science, v. $10,319 \mathrm{p}$

Chen, J.Y., Huang, D.Y., Peng, Q.Q., Chi, H.M., Wang, X.Q. and Feng, M., 2003, The first tunicate from the Early Cambrian of South China: Proceedings of the. National Academy of Sciences, v. 100, p. 8314-8318.

Cuif, J.P., 1977, Arguments pour une relation phylétique entre les madréporaires paléozoiques et ceux du Trias. Implications systématiques de l'analyse microstructurale des Madréporaires triasiques: Mémoires de la Societé Géologique de France, v. 129, p. 1-54.

Ezaki, Y., 1998, Paleozoic Scleractinia: progenitors or extinct experiments? Paleobiology, v. 24, p. 227-234.

Fuchs, D., and Iba, Y., 2015, The gladiuses in coleoid cephalopods: homology, parallelism, or convergence?: Swiss Journal of Palaeontology, v. 134, p. $187-197$.

Hallas, J.M., Simison, W.B., and Gosliner, T.M., 2016, Dating and biogeographical patterns in the sea slug genus Acanthodoris Gray, 1850 (Mollusca, Gastropoda, Nudibranchia): Molecular Phylogenetics and Evolution, v. 97, p. 19-31.

Janiszewska, K., Stolarski, J., Kitahara, M.V., Neuser, R.D., and Mazur., M., 2015, Microstructural disparity between basal micrabaciids and other Scleractinia: new evidence from Neogene Stephanophyllia: Lethaia, v. 48, p. 417-428. 
Kouchinsky, A., Bengtson, S., Runnegar, B., Skovstedt, C., Steiner, M. and Vendrasco, M., 2012, Chronology of early Cambrian biomineralization: Geological Magazine, v. 149, p. 221-251.

Lamarck, J.-B. de, 1816, Histoire naturelle des animaux sans vertèbres, présentant les caractères généraux et particuliers de ces animaux, leur distribution, leurs classes, leurs familles, leurs genres, et la citation des principales espèces qui s'y rapportent; précédés d'une introduction offrant la determination des caractères essentiels de l'animal, sa distinction du vegetal et des autres corps naturels, enfin, l'exposition des principes fondamentaux de la zoologie. Tome troisième: Paris, Deterville/Verdière, p. $80-127$.

Lambert, G., Lambert, C.C., and Lowenstam, H.A., 1990, Protochordate bimineralization, in Carter, J.G., ed., Skeletal Biomineralization: Patterns, Processes and Evolutionary Trends: New York, Van Nostrand Reinhold, v. 1, p. $165-173$.

Landing, E., Jonathan, B., Antcliffe, J.B., Brasier, M.D., and English, A.B., 2015, Distinguishing Earth's oldest known bryozoan (Pywackia, late Cambrian) from pennatulacean octocorals (Mesozoic-Recent): Journal of Paleontology, v. 89, p. 292-317.

Lowenstam, H.A., and Margulis, L., 1980, Evolutionary prerequisites for early Phanerozoic calcareous skeletons: Biosystems, v. 12, p. 27-41.

Lowenstam, H.A., and Weiner, S., 1989, On Biomineralization: Oxford, University Press, $324 \mathrm{p}$.

Łukowiak, M., Dumitriu, S.D., and Ionesi, V., 2016, First fossil record of early Sarmatian didemnid ascidian spicules (Tunicata) from Moldavia: Geobios, v. 49, p. 201-209.

Marin, F., Pokroy, B., Luquet, G., Layrolle, P., and De Groot, K., 2007, Protein mapping of calcium carbonate biominerals by immunogold: Biomaterials, v. 28 , p. $2368-2377$.

Monniot, C., 2002, Stolidobranch ascidians from the tropical western Indian Ocean: Zoological Journal of the Linnean Society, v. 135, p. 65-120.

Monniot, F., 1970, Les spicules chez les tuniciens aplousobranches: Archives de Zoologie Expérimentale et Générale, v. 111, p. 303-331.

Monniot, F., and Buge, E., 1971, Les spicules d'ascidies fossiles et actuelles: Annales de Paléontologie (Invertébres), v. 58, p. 93-105.

Montanari-Gallitelli, E., 1956, Khmeria and Trachypsammia from the Permian of Sosio, Sicily: Journal of Paleontology, v. 30, p. 876-882.

Roden, V. J., Hausmann, I. M., Nützel, A., Seuss, B., Reich, M., Urlichs, M., Hagdorn, H., and Kiessling, W., 2019, Fossil liberation: a model to explain high biodiversity in the Triassic Cassian Formation: Palaeontology, v. 62, 18 p. https://doi.org/10.1111/pala.12441

Sandberg, P.A., 1983, An oscillating trend in Phanerozoic non-skeletal carbonate mineralogy: Nature, v. 305, p. 19-22.

Schöne, B.R., Dunca, E., Fiebig, J., and Pfeiffer, M., 2005, Mutvei's solution: an ideal agent for resolving microgrowth structures of biogenic carbonates: Palaeogeography, Palaeoclimatology, Palaeoecology, v. 228, p. 149-166.

Spiro, B.F., 1971, Infrastructure and chemistry of the skeleton of Tubipora musica Linné: Bulletin of the Geological Society of Denmark, v. 20, p. 279-284.

Stanley, G.D., 2003. The evolution of modern corals and their early history: Earth Science Reviews, v. 60, p. 195-225.

Stanley, S.M., 2006, Influence of seawater chemistry on biomineralization throughout Phanerozoic time: paleontological and experimental evidence: Palaeogeography, Palaeoclimatology, Palaeoecology, v. 232, p. $214-236$

Stolarski, J. 1996, Gardineria-a scleractinian living fossil: Acta Palaeontologica Polonica, v. 41, p. 339-367.

Stolarski, J., Kitahara, M.V., Miller, D.J., Cairns, S.D., Mazur, M. and Meibom, A., 2011, The ancient evolutionary origins of Scleractinia revealed by azooxanthellate corals: BMC Evolutionary Biology, v. 11, art. 316, p. 1-10. doi:10.1186/1471-2148-11-316

Sun, C.Y., Marcus, M.A., Frazier, M.J., Giuffre, A.J., Mass, T., and Gilbert, P.U.P.A., 2017, Spherulitic growth of coral skeletons and synthetic aragonite: nature's three-dimensional printing: ACS Nano, v. 11, p. 66126622 .

Sutton, M., Perales-Raya, C., and Gilbert, I., 2016, A phylogeny of fossil and living neocoleoid cephalopods: Cladistics, v. 32, p. 297-307.

Tchudinova, I.I., 1965, Typus Coelenterata. Class Anthozoa. Subclass Tabulata: Trudy Paleontologicheskogo Instituta Akademii Nauk SSSR, v. 108, p. 150-156. [in Russian]

Thomas, R.D.K., and Reif, W.-E., 1991, Design elements employed in the construction of animal skeletons, in Schmidt-Kitttler, N., and Vogel, K., eds., Constructional Morphology and Evolution: Berlin, Heidelberg, SpringerVerlag, p. 283-290.

Thomas, R.D.K., Shearman, R.M., and Stewart, G.W., 2000, Evolutionary exploitation of design optics by the first animals with hard skeletons: Science, v. 288, p. 1239-1242.

Van Name, W., 1945, The North and South American ascidians: Bulletin of the American Museum of Natural History, v. 84, p. 1-476.

Varol, O., and Girgis, M.H., 1994, New taxa and taxonomy of some Jurassic and Cretaceous calcareous nannofossils: Neues Jahrbuch für Geologie und Paläontologie, Abhandlungen, v. 192, p. 221-253.

Varol, O., and Houghton, S.D., 1996, A review and classification of fossil didemnid ascidian spicules: Journal of Micropaleontology, v. 15, p. $135-149$.

Wendt, J., 1984, Skeletal and spicular mineralogy, microstructure and diagenesis of coralline calcareous sponges: Palaeontographica Americana, v. 54, p. 326-336.

Wendt, J. 1990, The first aragonitic rugose coral: Journal of Paleontology, v. 64, p. 335-340.

Wendt, J., 2018, The first tunicate with a calcareous exoskeleton (Upper Triassic, northern Italy): Palaeontology, v. 61, p. 575-595.

Wollscheid-Lengelin, E., Boore, J., Brown, W., and Wägele, H., 2001, The phylogeny of Nudibranchia (Opisthobranchia, Gastropoda, Mollusca) reconstructed by three molecular markers: Organisms, Diversity, \& Evolution, v. 1, p. 241-256.

Yakovlev, N.N., 1939, Nouveaux genres de coraux Tabulata du Permien Inferieur del'Oural et du basin du Donetz: Comptes Rendus (Doklady) de 1'Académie des Sciences de 1'URSS, v. 24, p. 629-632.

Zardini, R., 1981, Fossili cassiani (Trias medio-superiore). Atlante dei bivalvi della Formazione di S. Cassiano raccolti nella regione dolomitica attorno a Cortina d'Ampezzo: Cortina d'Ampezzo, Edizioni Ghedina, $14 \mathrm{p}$.

Zhuravlev, A.Y., and Wood, R.A., 2018, The two phases of the Cambrian Explosion: Nature, Scientific Reports, v. 8, article 16656, p. 1-10.

Accepted: 16 December 2019 